\title{
PROSPECTIVE EVALUATION OF INJURIES OCURRED DURING A PROFESSIONAL SOCCER CHAMPIONSHIP IN 2016 IN SÃO PAULO, BRAZIL
}

\section{AVALIAÇÃO PROSPECTIVA DAS LESÕES DURANTE O CAMPEONATO PAULISTA DE FUTEBOL DE 2016}

\author{
Gustavo Gonçalves Arlanil ${ }^{1}$, Paulo Henrique Schmidt Lara ${ }^{1}$, Diego Costa Astur ${ }^{1}$, André Pedrinelli ${ }^{2}$, \\ Jorge Roberto Pagura ${ }^{3}$, MoIsés COHen ${ }^{1}$ \\ 1. Department of Orthopedics and Traumatology, Centro de Traumatologia do Esporte, Universidade Federal de São Paulo, São Paulo, SP, Brazil. \\ 2. Instituto de Ortopedia e Traumatologia, Hospital das Clínicas, Faculdade de Medicina da Universidade de São Paulo, São Paulo, SP, Brazil. \\ 3. Department of Neurology and Neurosurgery, Faculdade de Medicina do ABC, Santo André, SP, Brazil.
}

\section{ABSTRACT}

Objective: To identify the incidence of injuries, their main characteristics, and the way they were managed throughout 2016 in two major series of a professional soccer championship in São Paulo, Brazil. Methods: This prospective study used an electronic questionnaire previously developed by the Medical Committee of the Paulista Soccer Federation which was sent to the team doctors after each match. Results: Two hundred and fifty-nine injuries occurred during 361 matches, and the incidence of injury per 1000 hours of game play was 21.32. Strikers were the most affected by injury; the most frequent diagnosis was muscle injury and the legs were predominantly affected. Most of the injuries occurred in the last 15 minutes of the first half and only $7.7 \%$ required surgical treatment. Conclusions: Muscle injuries were the most frequent, with most occurring in forwards and in the legs. Approximately half of the injuries occurred after contact and the vast majority was treated without surgery. MRI was the most requested exam and most injuries were classified as moderate (8 to 28 lost play days). Level of Evidence III, Study of Non Consecutive Patients; Without Consistently Applied Reference "Gold" Standard.

Keywords: Soccer. Athletes. Wounds and injuries. Epidemiology.

\section{RESUMO}

Objetivo: Identificar a incidência de lesões, suas principais características e a maneira como foram conduzidas durante todo o ano de 2016 nas duas principais séries (A1 e A2) do Campeonato Paulista. Métodos: Realizou-se um estudo prospectivo por meio de questionário eletrônico previamente desenvolvido pelo Comitê Médico da Federação Paulista de Futebol, que foi enviado aos médicos dos times das séries A1 e A2 do Campeonato Paulista de Futebol após cada rodada. Resultados: Houve 259 lesões durante 361 jogos, com incidência de 21,32 lesões por 1.000 horas de jogo ao se agrupar as duas séries do Campeonato Paulista. Os atacantes foram os mais envolvidos, sendo as lesões musculares as mais frequentes e os membros inferiores os mais afetados. A maioria das lesões ocorreu nos últimos 15 minutos do primeiro tempo e somente $7,7 \%$ das lesões precisaram de tratamento cirúrgico. Conclusões: As lesões musculares são as mais frequentes, sendo que a maioria ocorreu em atacantes e nos membros inferiores. Cerca de metade das lesões ocorreu após contato e a maioria absoluta das lesões foi tratada de forma não cirúrgica. A ressonância magnética foi o exame mais solicitado e a maior parte das lesões foi classificada como de gravidade moderada (8 a 28 dias de afastamento). Nível de Evidência III, Estudo de Pacientes Não-Consecutivos; Sem Padrão de Referência "Ouro" Aplicado Uniformente.

Descritores: Futebol. Atletas. Ferimentos e lesões. Epidemiologia.

Citation: Arliani GG, Lara PH, Astur DC, Pedrinelli A, Pagura JR, Cohen M. Prospective evaluation of injuries ocurred during a professional soccer championship in 2016 in São Paulo, Brazil. Acta Ortop Bras. [online]. 2017;25(5):212-5. Available from URL: http://www.scielo.br/aob.

\section{INTRODUCTION}

Soccer is the most popular sport in the world, with an estimated 240 million amateur athletes and at least 200,000 professional athletes. It is a sport that covers all age ranges, both sexes, and presents a high rate of injuries (70 injuries per 1000 hours of play). ${ }^{1}$ Soccer features short, fast, and non-continuous movements like acceleration, deceleration, changes in direction and leaps, and also involves extensive contact, which leads to injuries. . $^{2,3}$

National entities from countries as USA and UEFA tend to characterize and disclose injuries from their major championships in order to develop programs to prevent and reduce morbidity caused by soccer-related injuries. Previous studies have reported

All authors declare no potential conflict of interest related to this article.

Work performed at the Universidade Federal de São Paulo, Centro de Traumatologia do Esporte, Department of Orthopedics and Traumatology, São Paulo, SP, Brazil. Correspondence: Rua Estado de Israel, 636, Vila Clementino, São Paulo, SP, Brazil. 04022-00. ggarliani@hotmail.com 
that muscle injuries, contusions, and sprains comprise $75 \%$ of injuries in professional soccer players, with the majority affecting i the legs (60-85\%). ${ }^{4}$

Brazil has a large number of practitioners and is considered to have some of the best players in the world. The data are sparse and little is known about types of injuries and how and when they occur, which makes it difficult to prevent and treat these injuries and to rehabilitate the players. ${ }^{5}$

The objective of this study was to identify the incidence of injuries, their main features, and how they were handled throughout 2016 during the two main series (A1 and A2) of the Campeonato Paulista (São Paulo State Championship).

\section{MATERIALS AND METHODS}

This research project was approved by the institutional review board (number 56723616.3.0000.5505).

This prospective study was conducted using an electronic questionnaire previously developed by the Medical Committee of the Paulista Soccer Federation and sent to the physicians for the teams in series A1 and A2 after each round of the 2016 São Paulo State Championship. All participants signed the Informed Consent Form prior to participating in the study.

A questionnaire was sent after each round to assess the incidence of injuries and their characteristics. The questionnaire consisted of 10 questions about the characteristics of the game, the athlete, and of the injury. (Annex 1)

The concept used to define soccer injuries was the same chosen by Fuller et al. ${ }^{6}$ for the 2005 FIFA consensus, describing them as: "Any physical complaint sustained by a player that results from a football match or football training, irrespective of the need for medical attention or time loss from football activities."

To evaluate the outcome of the injuries reported, a questionnaire was sent for each injury which occurred and was completed after the athlete returned to training and game play. The questionnaire was comprised of six questions spanning from the complementary examination performed to the final diagnosis. (Annex 2)

To obtain the game schedules, we requested the game records from the Paulista Soccer Federation and divided the schedules as follows: morning (start before noon), afternoon (start before 6 p.m.), and night (start after 6 p.m.).

To assess the risk of injury we calculated the incidence of injury, which is expressed by the number of injuries per 1000 hours of exposure. ${ }^{6,7}$ To calculate exposure in games we used the following formula:

Exposure $=$ number of injuries in games $x$ number of players participating in the game $x$ game duration in minutes / 60'

To calculate the incidence in games we used the following formula:

Incidence $=$ number of injuries in games $\times 1000$ hours/time of exposure

\section{Statistical analysis}

We used statistical tests because the data were quantitative and continuous. We used the equality of two proportions test to characterize the distribution of the relative frequency of the qualitative variables. Differences with $p<0.05$ were considered statistically significant. SPSS V17 software was used to conduct the analysis.

\section{RESULTS}

The mean age of the injured players was 26.8 years, and the mean number of days lost as a result of injuries was 23.2. The fewest games took place in the morning (11.2\%), 34.1\% of the games took place in the afternoon, and $54.7 \%$ took place at night.

During a total of 361 games 259 injuries were described, with an average of 0.71 injuries per game. Of the total, $27 \%$ of the injuries occurred in strikers, $17.4 \%$ in attacking midfielders, $17.4 \%$ in defensive midfielders, $17 \%$ in full-backs, $15.8 \%$ in central-backs, and $5.4 \%$ in goalkeepers. Most injuries occurred at the end of the first half, between the 31- and 45-minute mark (25.1\%). (Figure 1)

As for location, the most frequent injuries were to the legs (73.4\%), head (15.1\%), arms (6.2\%), and trunk (5.4\%). The right side was most frequently affected $(45.6 \%)$ and $17.8 \%$ of injuries were not classifiable as one side or the other. Contact was involved in $49 \%$ of the injuries. As for type of injury, muscle strains were the most common (39.8\%), followed by sprains (20.5\%) and contusions (16.6\%). (Figure 2) The most common initial diagnoses were hamstring muscle injury (23.9\%), adductor muscle injury (7.7\%), injury to the lateral ligament of the ankle (5.8\%), quadriceps muscle injury (5\%), concussion (3.9\%), and facial cut/contusion (3.9\%).

During series A1, there were 24.16 injuries per 1000 hours of play, and in series A2 there were 19.10 injuries per 1000 hours of play. For the two series combined, there were 21.32 injuries per 1000 hours of game play.

When requested, the most common complementary exams performed were magnetic resonance imaging (36.7\%) and ultrasound (28.2\%), followed by X-rays (15.4\%) and computed tomography (6.6\%). Only $7.7 \%$ of the injuries required surgery. The most common injuries (34.4\%) were considered moderate according to the severity scale, with lost time of 8 to 28 days. (Figure 3 )

\section{DISCUSSION}

The mean number of days the athletes lost per injury was 23.2. There was an incidence of 21.32 injuries per 1000 hours of game play for

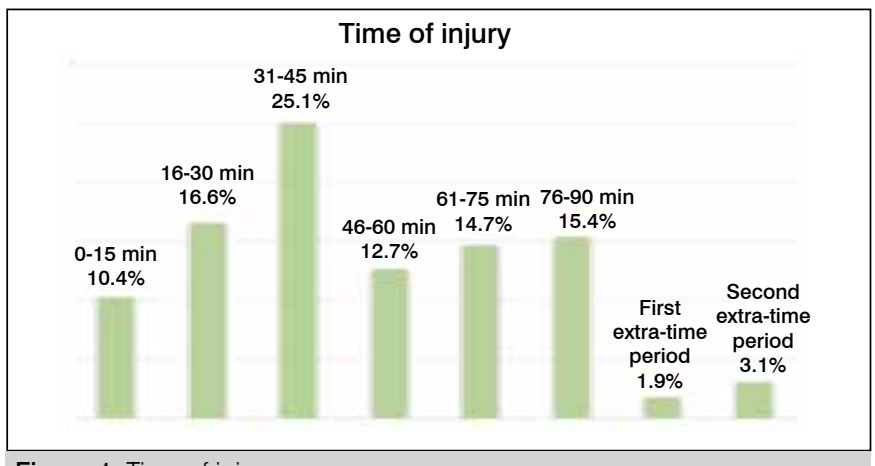

Figure 1. Time of injury.

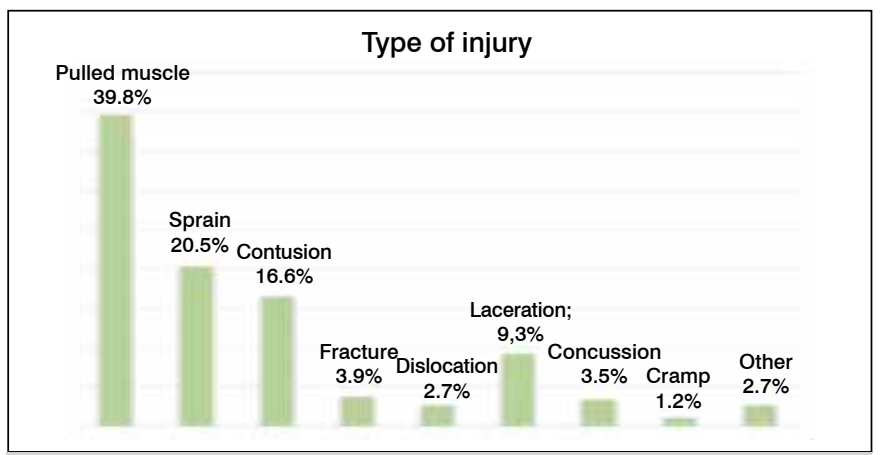

Figure 2. Type of injury 


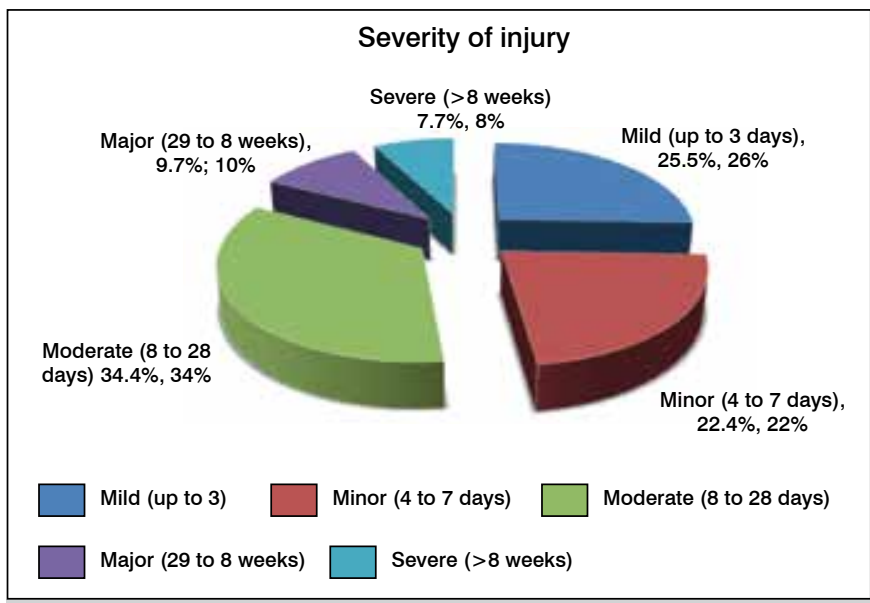

Figure 3. Severity of injuries.

both series of the São Paulo State Championship soccer championship combined. Most injuries occurred during the last 15 minutes of the first half and only $7.7 \%$ of the injuries required surgical treatment.

A number of studies have investigated the incidence and main causes of soccer injuries. ${ }^{1,7-11}$ The mean age of the injured players in this present study was 26.8 years, higher than described in the literature. ${ }^{5,12}$ On average, athletes lost 23.2 days of play after injury, more than indicated in the study by Stubbe et al., ${ }^{13}$ who found an average of 8 days of lost play. One possible explanation for this high average was the presence of 10 cases of tears in the anterior cruciate ligament of the knee, which led to an average of more than 6 months of lost play. We found an average of 0.71 injuries per game, below the number found in several studies in the literature including Pedrinelli et al. ${ }^{1}$ and Junge and Dvorak, ${ }^{14}$ who found 2.4 injuries per game. This difference may be because our study assessed more players than the other studies.

As for prevalence according to the diagnosis, contusions, muscle strains and sprains are the most frequent injuries in the literature, most commonly in the legs. ${ }^{1,15-18}$ Our study shows similar results; not only were leg injuries the absolute majority (73.4\%), but muscle strains and sprains were most common. Strikers were the most affected by injuries; this finding counters the results of previous studies in which midfielders were most affected. ${ }^{19,20}$ This may be because these studies did not divide midfield players into defensive and attacking midfielders as we did in this present study. As for the incidence of injuries per 1000 hours of play, we found results that are within the range found in the literature, from 15 to 70 injuries per 1000 hours of game play. ${ }^{1,21-23}$ It should be noted that the values vary so widely in previous studies because of differences in study design, data collection methods, and the definition of injury. ${ }^{24}$ Our study also differed from the literature in terms of the time of injury, which was more common between the 31 and 45 minute mark, while other studies have shown that most injuries occurred in the last 30 minutes of the game. ${ }^{1,22}$ In our study, $49 \%$ of the injuries occurred after contact, results which are similar to the findings by Pedrinelli et al., ${ }^{1}$ but less than the literature in which more than $70 \%$ of injuries occur after contact. ${ }^{22,23}$

The most commonly requested supplementary examination after injury was magnetic resonance imaging; this may result from the fact that muscle injuries were most common, and these types of injuries are generally assessed via this examination. In our study, most injuries were considered moderate (8 to 28 days of lost play), which is similar to the findings by Stubbe et al. ${ }^{13}$ but differs from Pedrinelli et al. ${ }^{1}$ and Cohen et al., ${ }^{12}$ who found mild injuries (4 to 7 days lost) to be most common. Only $7.7 \%$ of the injuries required surgery, which results from the fact that the vast majority of injuries which affect soccer players (such as muscle strains and contusions) are managed conservatively.

This study has some methodological limitations. There is the possibility of outcome information bias, since precise data on the injuries may have been altered or even omitted by the team physicians. Furthermore, the study evaluated acute injuries which occurred during games, and consequently chronic injuries as well as those which occurred during practice and diseases unrelated to sports were not recorded. In a study conducted during the 2010 World Cup by Dvorak et al., ${ }^{25}$ injuries that occurred during practice had very different diagnoses than those which occurred during the game play, but the severity of the injuries was similar and non-sports diseases affected approximately $12 \%$ of the players. We believe it is important to expand medical supervision for injuries during practice and off-field diseases in the players. Another point was that exposure time was calculated using 22 players and 90 minutes of play. A more precise method would be to consider extra time or the real time for each game and the number of minutes of exposure for each individual player.

The information in this study is critical to preventing new injuries in soccer. The data will allow athletes and medical staff in clubs and federations to carry out preventative programs aiming at reducing the incidence of injuries in the sport.

\section{CONCLUSIONS}

Muscle injuries were the most frequent, with most injuries affecting strikers and the legs. Approximately half of the injuries occurred after contact and most were treated non-surgically. Magnetic resonance imaging was the most frequently requested exam and most of the injuries were classified as moderate (with 8 to 28 days lost).

\section{ACKNOWLEDGMENTS}

We wish to thank the Paulista Soccer Federation and their president Reinaldo Carneiro Bastos for providing the data for this study.

AUTHORS' CONTRIBUTIONS: Each author made significant individual contributions to this manuscript. GGA (0000-0003-4371-5041)*, PHSL (0000$0002-1623-2071)^{*}$, and DCA $(0000-0002-2608-2118)^{*}$ drafted the manuscript. AP $(0000-0002-8449-7493)^{\star}$, JRP $(0000-0001-7952-5085)^{*}$, and MC $(0000-$ $0001-7671-8113)^{*}$ conducted the bibliographical research, reviewed the manuscript, and contributed to the intellectual concept of the study. ${ }^{*}$ ORCID (Open Researcher and Contributor ID).

\section{REFERENCES}

1. Pedrinelli A, Cunha Filho GAR, Thiele ES, Kullak OP. Estudo epidemiológico das lesões no futebol profissional durante a Copa América de 2011, Argentina. Rev Bras Ortop. 2013;48(2):131-6.

2. Matsudo V, Martin V. Lesões no futebol profissional. Projeto Piloto. Ambito Med Desp. 1995;12:5-10

3. Keller CS, Noyes FR, Buncher CR. The medical aspects of soccer injury epidemiology. Am J Sports Med. 1987;15(3):230-7.

4. Ekstrand J, Hägglund $M$, Waldén $M$. Injury incidence and injury patterns in professional football: the UEFA injury study. Br J Sports Med. 2011;45(7):553-8

5. de Freitas Guina Fachina RJ, Andrade Mdos S, Silva FR, Waszczuk-Junior $\mathrm{S}$, Montagner PC. Descriptive epidemiology of injuries in a Brazilian premier league soccer team. Open Access J Sports Med. 2013;4:171-4. 
6. Fuller CW, Ekstrand J, Junge A, Andersen TE, Bahr R, Dvorak J, et al. Consensus statement on injury definitions and data collection procedures in studies of football (soccer) injuries. Br J Sports Med. 2006;40(3):193-201.

7. Hägglund M, Walden M, Til L, Pruna R. The importance of epidemiological research in sports medicine. Apunts Med Esport. 2010;45(166):57-9.

8. Inklaar H. Soccer injuries. II: Aetiology and prevention. Sports Med. 1994; 18(2):81-93.

9. Ekstrand J, Gillquist J. The avoidability of soccer injuries. Int J Sports Med. 1983;4(2):124-8.

10. Junge A, Dvorak J. Soccer injuries: a review on incidence and prevention. Sports Med. 2004;34(13):929-38

11. Inklaar H. Soccer injuries. I: Incidence and severity. Sports Med. 1994;18(1):55-73.

12. Cohen M, Abdalla RJ, Ejnisman B, Amaro JT. Lesões ortopédicas no futebol. Rev Bras Ortop. 1997;32(12):940-4.

13. Stubbe JH, van Beijsterveldt AM, van der Knaap S, Stege J, Verhagen EA, van Mechelen W, et al. Injuries in professional male soccer players in the Netherlands: a prospective cohort study. J Athl Train. 2015;50(2):211-6.

14. Junge A, Dvorak J. Injury surveillance in the World Football Tournaments 1998-2012. Br J Sports Med. 2013;47(12):782-8.

15. Schmidt-Olsen S, Bünemann LK, Lade V, Brassøe JO. Soccer injuries of youth Br J Sports Med. 1985;19(3):161-4

16. McMaster WC, Walter M. Injuries in soccer. Am J Sports Med. 1978;6(6):354-7.
17. Ekstrand J, Nigg BM. Surface-related injuries in soccer. Sports Med. 1989;8(1):56-62

18. Astur DC, Novaretti JV, Uehbe RK, Arliani GG, Moraes ER, Pochini AC, et al. Muscle injury: current perspectives and trends in Brazil. Rev Bras Ortop. 2014;49(6):573-80

19. Morgan BE, Oberlander MA. An examination of injuries in major league soccer The inaugural season. Am J Sports Med. 2001;29(4):426-30.

20. Noya Salces J, Gómez-Carmona PM, Gracia-Marco L, Moliner-Urdiales D, Sillero-Quintana M. Epidemiology of injuries in First Division Spanish football. J Sports Sci. 2014;32(13):1263-70.

21. Eirale C, Farooq A, Smiley FA, Tol JL, Chalabi H. Epidemiology of football injuries in Asia: a prospective study in Qatar. J Sci Med Sport. 2013;16(2):113-7.

22. Aoki H, O'Hata N, Kohno T, Morikawa T, Seki J. A 15-year prospective epidemiological account of acute traumatic injuries during official professional soccer league matches in Japan. Am J Sports Med. 2012;40(5):1006-14.

23. Pangrazio O, Forriol F. Epidemiology of soccer players traumatic injuries during the 2015 America Cup. Muscles Ligaments Tendons J. 2016;6(1):124-30.

24. Arliani GG, Belangero PS, Runco JL, Cohen M. The Brazilian Football Association (CBF) model for epidemiological studies on professional soccer player injuries. Clinics (Sao Paulo). 2011;66(10):1707-12.

25. Dvorak J, Junge A, Derman W, Schwellnus M. Injuries and illnesses of football players during the 2010 FIFA World Cup. Br J Sports Med. 2011;45(8):626-30.

Annex 1. Injury mapping questionnaire.

Mapping of Injuries from the 2016 Campeonato Paulista (São Paulo Professional Soccer Championship)

1. What game are you reporting below?

2. Were there injuries in this game?

( ) Yes ( ) No

3. What is the athlete's date of birth?

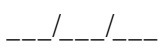

4. What is the athlete's position?
( ) Goalkeeper
( ) Outside back
( ) Central defender
( ) Defensive midfielder
( ) Midfielder
( ) Forward

5. When did the injury occur?
( ) 0-15 min
( ) 16-30 min
( ) 31-45 min.
( ) $46-60 \mathrm{~min}$
( ) 61-75 min.
( ) $76-90 \mathrm{~min}$
( ) Extra time, first half
( ) Extra time, second half

6. Area of body where injury occurred:
( ) Head
( ) Trunk
( ) Arm
( ) Leg

7. Side of injury:
( ) Right
( ) Left
( ) Not applicable

8. Type of injury
( ) Pulled muscle
( ) Sprain
( ) Contusion
( ) Fracture
( ) Dislocation
( ) Cut-contusion trauma
( ) Concussion
( ) Cramp
( ) Others

9. Did the injury occur after contact or collision with the ball, the goalposts, or other athlete?
( ) Yes
( ) No

10. Initial diagnosis (likely)

\section{Follow-up of Injuries from the 2016 Campeonato Paulista (São Paulo Professional Soccer Championship)}

1. What complementary examinations were requested?
( ) None
( ) X-ray
( ) US
( ) CT
( ) MRI
( ) Other (please specify)

2. Did the injury require surgery?
( ) Yes
( ) No
( ) If so, what?

4. Injury Severity Scale:

( ) Mild (up to 3 days lost) ( ) Minor (up to 7 days lost)

( ) Moderate (8 to 28 days lost) ( ) Major (29 days to 8 weeks lost)

( ) Severe ( $>8$ weeks lost)

5. Final diagnosis

3. Days lost: 